\title{
Article
}

\section{Navigating the ambiguous policy landscape of student participation}

\author{
Graham, A, Bessell, S, Adamson, E, Truscot, J, Simmons, C, \\ Thomas, Nigel Patrick, Gardon, L and Johnson, A \\ Available at http://clok.uclan.ac.uk/24677/ \\ Graham, A, Bessell, S, Adamson, E, Truscot, J, Simmons, C, Thomas, Nigel \\ Patrick ORCID: 0000-0002-5310-9144, Gardon, L and Johnson, A (2019) \\ Navigating the ambiguous policy landscape of student participation. Journal of \\ Education Policy, 34 (6). pp. 789-811. ISSN 0268-0939
}

It is advisable to refer to the publisher's version if you intend to cite from the work. http://dx.doi.org/10.1080/02680939.2018.1527945

For more information about UCLan's research in this area go to http://www.uclan.ac.uk/researchgroups/ and search for <name of research Group>.

For information about Research generally at UCLan please go to http://www.uclan.ac.uk/research/

All outputs in CLoK are protected by Intellectual Property Rights law, including Copyright law. Copyright, IPR and Moral Rights for the works on this site are retained by the individual authors and/or other copyright owners. Terms and conditions for use of this material are defined in the policies page.

\section{CLoK}

Central Lancashire online Knowledge www.clok.uclan.ac.uk

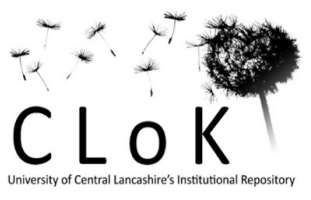


Final Author Version Submitted to: Journal of Educational Policy

\title{
Navigating the ambiguous policy landscape of student participation
}

\author{
Authors: \\ Anne Graham (Centre for Children and Young People, Southern Cross University) \\ Sharon Bessell (Australian National University) \\ Elizabeth Adamson (University of NSW) \\ Julia Truscott (Centre for Children and Young People, Southern Cross University) \\ Catharine Simmons (Centre for Children and Young People, Southern Cross University) \\ Nigel Thomas (University of Central Lancashire) \\ Lyn Gardon (NSW Government Department of Education) \\ Andrew Johnson (NSW Advocate for Children and Young People)
}

\begin{abstract}
Student participation at school is receiving heightened attention through international evidence connecting it to a range of benefits including student learning, engagement, citizenship and wellbeing, as well as to overall school improvement. Yet the notion of student participation remains an ambiguous concept, and one that challenges many deeply entrenched norms of traditional schooling.
\end{abstract}

Informed by understandings of 'participation' linked to the UN Convention on the Rights of the Child, this article takes the Australian state of New South Wales (NSW) as a case study to explore how student participation is currently articulated in educational policy. It reports the findings of an analysis of 142 state and federal government policy-related documents, along with qualitative interview data from nine policy personnel. The findings suggest that students are conceptualised within these policies in contradictory ways, interpretations of participation are diverse yet frequently instrumentalist, and there is little conceptual coherence across the educational policy landscape in NSW in relation to 'student 
participation'. The findings are discussed in light of international interest around student participation. The analytical framework used in this analysis is proposed as a possible tool for critically examining the place and purpose of student participation at school, regardless of jurisdiction.

Keywords: student participation, student voice, children's rights, policy analysis

\section{Introduction}

Children's participation was placed firmly on the policy agenda in 1989 with the adoption by the United Nations' General Assembly of the Convention on the Rights of the Child (UNCRC). In the ensuing decades the idea that children should, and indeed have the right to, express their views on matters affecting them has influenced thinking, discourse and policy globally across many sectors (see Bessell and Gal 2009; Fitzgerald et al. 2010; Lundy et al. 2012). In addition to being a right, and more justly recognising children as a social group, it has now long been argued that children's participation improves services, leads to better decision-making, enhances safety and protection, improves engagement and enriches adult-child relations (Bessell and Gal 2009; Mannion 2007; Graham et al. 2017). Accordingly, research indicates that student participation has the potential to transform schooling, build stronger school communities, engage and motivate students and strengthen student wellbeing (Barber 2009; Fielding 2015; Mannion, Sowerby and I'Anson 2015).

Despite these benefits, student participation challenges a number of entrenched assumptions and long-standing educational conventions (Arnot and Reay 2007; Lundy and Cook-Sather 2016; Sargeant and Gillett-Swan 2015). These centre mainly around the hierarchy and power dynamics inherent in adult-child relations, which are underpinned by socially constructed beliefs about children's capabilities and appropriate roles in the school setting (James and Prout 2015; Mannion 2010). Adding to these challenges, 
student participation is an ambiguous concept, applied to anything from simply attending school and 'participating' in lessons to collaborative decision-making with adults (Rudduck and Fielding 2006). This makes it difficult to articulate clearly in policy and, correspondingly, to meaningfully implement and evaluate in practice. Combined, the enduring social expectations and conceptual ambiguity place student participation at risk of becoming a 'hurrah' term - widely lauded and broadly applied, but lacking the rigour and momentum to achieve the cultural and systemic changes necessary to realise its full potential (Lundy 2007; Pearce and Wood 2016).

This paper takes New South Wales (NSW), Australia's most populous state, as a case study example, to examine how student participation is currently articulated in education policy (at a state and federal level). The findings are drawn from a large mixed method study, entitled 'Improving Wellbeing through Student Participation at School', which was conducted in four phases. The policy analysis comprised the first, foundational phase and involved the analysis of 142 policy-related documents relevant to schooling in NSW. Given the aforementioned issues, particular attention was given in the analysis to the ways in which both 'students' and 'participation' are framed. Complementing the policy analysis, interview data were gathered from educational sector policy personnel $(n=9)$, offering insight into the evolving student participation agenda. Together, the findings shed light on the conceptualisation and positioning of student participation across education-related policy in the state. Examined in light of international research surrounding student participation, the findings offer valuable insights for educational sectors in other comparable jurisdictions.

\section{Background}

Children's Participation at School 
The UNCRC (1989), ratified by almost every country worldwide, has been a key turning point in challenging beliefs and assumptions about children and their status, particularly in regard to participation (see Bessell and Gal 2009; Fitzgerald et al. 2010; Lundy 2007). Not only do a series of articles afford children 'rights to participation' (Articles 12-15), the requirement that children's views be heard on all matters affecting their lives and that these be given due weight (Article 12) is positioned as one of the four overarching general principles of the Convention. This places the child's 'voice' as central to the interpretation and implementation of all other rights, including their education rights (Articles 28 and 29).

Through entitling children to participatory rights, the UNCRC has acted at a global political and legal level to help increase the recognition of children, traditionally a highly marginalised or 'Othered' social group (Fitzgerald et al. 2010; Thomas 2007; 2012). This has engendered on-going debate about how to conceive of children's place in society. Are they 'beings' or 'becomings', 'citizens' or 'citizens-in-waiting'? How might their relative immaturity and dependence be accounted for? Some such questions are particularly challenging in schooling, where completely dispensing with the notion of children as 'becomings' raises questions surrounding the very purpose of education (Quennerstedt and Quennerstedt 2014) and presents a considerable challenge to adult authority in schools (Lundy 2007; Mannion 2007). Such issues have been so politically insurmountable in the US that they are cited as contributing to their resistance to ratifying the Convention (Kilbourne 1998).

Perhaps not surprisingly then, even in countries that have ratified the UNCRC and have shown progress in other sectors (Lundy et al. 2012), compulsory schooling has often been slow to take up the challenge of children's participation, particularly if this might require structural change (Lundy \& Cook-Sather 2016). To date, student councils (called 
student representative councils (SRCs) in Australia) have remained the most ubiquitous vehicle, despite being frequently critiqued as unrepresentative, tokenistic and adult/teacher-led in their processes and decision making (Lundy 2007; Lundy et al. 2012; Quinn and Owen 2016). They have likely prevailed, not only because they are relatively easy to incorporate into traditional systems, but because they align with teachers' preferences for student voice to be channelled in an organised, containable way (despite students' preferred experiences of participation being those that occur more informally through relational engagement (Horgan et al. 2017)).

In this paper we take an inclusive understanding of student participation as something broader than solely SRCs, encompassing students' active involvement in decision-making at school, in learning, their education and life course, and as relational members of the school and broader community. Existing literature highlights that across these arenas, student participation is influenced by the spatial and social context of schooling (Arnot and Reay 2007; Lundy 2007; Mannion 2007, 2010; Shier 2001). At an overarching level, opportunities for students to participate are influenced by school as an institution - performance and curricular constraints, culture, structures and pedagogy which in turn are underpinned by adult beliefs and values regarding students' status and capabilities and the purpose of schooling (Lundy \& Cook-Sather, 2016; Mannion, 2010), including enduring concerns (from teachers, parents and even students) that expanding student participation might lead to potential chaos (Barber 2009; Mitra 2006).

Student participation efforts are also hampered at a relational level in practice by hierarchical adult-child relations (Lundy 2007; Robinson and Taylor 2013). Teachers exert hegemonic power in schools, with teachers positioned as experts and students schooled to seek the 'right' answer, to listen to teachers, respect their authority and obey the school rules (Arnot and Reay 2007; Mannion 2010; Mitra 2006, Pearce and Wood 
2016). Participation processes are also fraught by hegemonic power issues exerted via year group hierarchy and peer group social dynamics, where popularity and social acceptance can influence student contributions as well as their interest in taking part (Lundy 2007; Pearce and Wood 2016; Robinson and Taylor 2013). Thus, it is recognised that relational power dynamics influence what students say (or don't say) (Arnot and Reay 2007).

In addition to power tensions during the generation of 'voice', issues connected to power can also influence its reception and interpretation. In particular, school staff receive and interpret student 'voice/s' through an adult filter (Arnot \& Reay, 2007), which can influence perceptions by students that they will never really be 'heard,' fuelling disengagement. Adding to this, the voices that are 'heard' are frequently those put forward by articulate, engaged and 'well-behaved' students (Robinson and Taylor 2013). As such, there is a risk that student voice efforts could act to reinforce inequality (Arnot and Reay 2007; Pearce and Wood 2016), with some scholars even suggesting participation could be wielded as a neoliberal tool for engendering majority compliance with existing processes (Raby 2014).

In an effort to address the above issues, current scholarship on student participation has become increasingly aligned with Fielding's (see 2004, 2015) and Mannion's (2007, 2010) ideas, in calling for a shift from a focus on student voice to intergenerational dialogue and associated collaboration. In this work, young people's empowerment is not specifically correlated with autonomy, which can somewhat pitch children's agency against that of adults (Mannion 2007). Instead, they focus on intergenerational partnership (Bessell and Gal, 2009; Fielding, 2015; Horgan et al., 2017; Mannion 2010; Sargeant and Gillett-Swan 2015), with importance placed upon the relational foundations and the way in which these meld young people's need for care and recognition with their 
human rights both to participate in decision-making and to have a quality education (Lundy and Cook-Sather 2016). This work helps to challenge the limiting dichotomy of conceptualising children as either 'beomcings' or beings', with greater recognition that both students and teachers are continually evolving and learning from one another in the intergenerational space (Mannion 2007, 2010; Quennerstedt and Quennerstedt 2014; Sargeant and Gillet-Swan 2015). Such ideas are often linked to 'radical' or 'transformative' student participation (and teaching) in that, over time, the process of genuinely and openly listening and working together might lead to the challenging and subversion of current norms - student participation at school could lead to fundamental reconfigurations of the very structure and process of schooling.

\section{Student Participation in Educational Policy}

Policy can be understood as articulating a 'future state of affairs' (Rizvi and Lingard $2010,5)$, and has the potential to reinforce privilege and power, or to drive change. As such, educational policy, particularly in those countries that have ratified the UNCRC, has a key role to play - arguably an obligation - to articulate a vision for student participation that challenges current mindsets, expands understandings of fundamental issues such as power, and pushes the boundaries of existing participatory practices and the spaces within which this occurs. In addition, it would be somewhat paradoxical for educational policy, and particularly that on student participation, not to involve students in the development of these policies themselves. While not the central focus of this paper, the imperative for students to participate within the process of educational policymaking should not be overlooked.

A complexity for educational policy on student participation is that policy-making is not a neutral process (Rizvi and Lingard 2010). The kinds of structural and cultural 
constraints described above (regarding children's capabilities, status and appropriate roles) are no less active at the policymaking level. These are the current boundaries surrounding the expansion of children's participatory rights in the educational sector the extent of societal or political acceptance and reform with regards to the status of children in schools and in their education. A critical starting point for analysing educational policy on student participation, then, is to examine how current educational policy (implicitly or explicitly) positions students in the school context.

A further complexity for policy on children's participation in the school context is that its impetus has instrumental as well as intrinsic value. Throughout the above, we have focused largely on the intrinsic value - the influence of the rights discourse in framing principled beliefs around the just treatment of children and the idea that student participation represents a commitment to democratic values. These in turn can be connected to subsequent improvements in community, self-esteem and student wellbeing (Barber 2009; Fielding 2015; Fitzgerald et al. 2010). The instrumental value of student participation applies a future-focused lens to such benefits, suggesting participation has the potential to create more engaged and involved future citizens. Further, student participation can also be alluringly justified in terms of outcomes, with participation having been linked to improvements in student behaviour, engagement and achievement (Mannion, Sowerby and l'Anson 2015). In the context of compulsory education, it can be difficult to disentangle intrinsic and instrumental goals and, under the current system and climate, instrumental goals might be considered the more persuasive. Yet, the motivation and purpose behind student participation is important. It may influence the way in which student participation is approached, resourced and experienced (Thomas 2007), including the likelihood of opportunities being created for staff and students to critically examine the assumptions, values and opinions they bring to dialogic encounters (Pearce and Wood 
2016; Robinson and Taylor 2013). Therefore, in this analysis, in addition to examining how students are positioned in educational policy, it is critical to explore the different ways in which participation is framed.

In existing literature, Sinnema and Ludlow (2013) have examined curriculum reform across Australia, New Zealand and the UK, and identified student agency to be a central aspect of each jurisdiction's curriculum framework. Lundy (2012) has reflected on the influence of the UNCRC upon educational policy across European nations, which included brief discussion of progress surrounding Article 12 in school contexts. To date though, there has been no known analysis nationally or internationally of how student participation is articulated in educational policy nor how this is framed across different aspects of school life. This is a significant gap given the obligations upon countries who have ratified the UNCRC as well as the increasing presence of student participation as an implicit aspiration within contemporary education. Therefore, taking New South Wales as a case study, the analysis that follows seeks to contribute to international policymaking around student participation by examining the ways in which both 'students' and 'participation' are currently framed in NSW educational policy and what this signals in terms of likely practice around student participation in schools.

\section{Method}

\section{Overview}

As indicated above, the policy analysis reported here comprised the first, foundational phase of a much larger study. The policy analysis focused upon policy in its most recognised form - written documentation. However, in recognition of the reality that policy is also a 'process' surrounding a policy issue (Rizvi and Lingard, 2010), the documentation analysis is presented alongside interview data from policy personnel gathered during the qualitative phase of the study (Phase 2). Policy as 'process' could 
arguably also encompass the interpretation and implementation of a policy agenda, hence could warrant the inclusion of data at the school level. Phase 2 involved interviews with school staff and focus groups with Year 7-10 students across ten schools, but presentation of this data is beyond the scope of this paper. Instead the focus is upon the articulation of student participation in current educational policy, with insights from policy personnel on the direction in which this may be heading.

\section{The Policy Analysis}

In recognition of the imprecision surrounding 'participation', we adopted an explicitly broad and inclusive definition of policy for the analysis, with the aim of mapping the breadth of policies relating to 'participation' and revealing the diverse ways in which the term is used. We employed a hermeneutic approach, allowing for iterative sense making that was extended upon further in other phases of the research (Yanow, 2007).

In NSW, Government and Catholic schools together educate the majority of students, with $65.4 \%$ of children in the state attending Government schools and $21.4 \%$ attending Catholic schools (ABS 2016). Accordingly, the analysis included policies and related documents from both Government and Catholic school sectors in NSW, and relevant policies at the Commonwealth (federal) level which pertain to all school systems. A wide range of documents was included - policies, procedural documents and guidelines and associated programs, departmental strategic plans, and resources such as toolkits and templates. We acknowledge that these documents are very diverse in purpose and content, however we considered a broad approach to be essential for two reasons First, in endeavouring to ensure that no documents were prematurely excluded we chose not to treat the documents differently in terms of status. Second, we were conscious that educational policy may be accessed in a range of ways, with time-poor practitioners 
perhaps making more frequent reference to accompanying webpages or summaries than the full policy document. Given the added difficulty in definitively determining which documents influence practice, it was necessary for an analysis of this kind to be inclusive.

The policy analysis was undertaken in three stages. At each stage the number of documents identified as relevant was reduced and the level of analysis deepened, as outlined below.

\section{Stage 1: Collection and mapping of policies}

The first stage involved identification of relevant policies through on-line searches and advice from the research partners (the NSW Government and Catholic school systems). The identified policies were 'mapped' to different themes or areas, as detailed in Table 1 in the findings section below. An initial content analysis was then undertaken to systematically determine if and how student participation was represented in each document. The key terms searched for within the documents included: participation, involve, engage, consult, communicate, voice, views, perspective, connect, collaborate, inclusive. These terms were truncated (e.g. participat*) to ensure no variations were missed.

A brief series of questions was then asked of each document, with the aim of ensuring systematic analysis and avoiding impressionistic interpretations. The key questions were:

- What is the aim of the document/policy?

- Who is responsible for implementing the policy?

- What are the key words?

- What is the context of the key words?

Asking these questions provided sufficient information to know whether there was 'potential for participation', and hence whether a document should be included in the next 
stage of analysis. This filtering process led to the discarding of policies that did not deal with or include student participation (despite the word 'participation' sometimes being used). The analysis was completed manually, using Excel spreadsheets with links to the relevant documents and websites.

\section{Stage 2: Categorising how 'student participation' is used in policy}

For the Stage 2 analysis we developed an analysis tool that focused on the language used to depict student participation - as a means of discovering both the meaning of policies and the consequences for action. The typology was based upon existing literature and developed from a synthesis of prominent models of young people's participation, particularly those by Hart (1992), Holdsworth (2000), Lundy (2007), Rudduck and Fielding (2006), and Shier 2001. We identified the commonalties in the uppermost and lower tiers of these models and translated the ideas into the language of contemporary childhood scholars, voice scholarship and rights-based approaches (Arnot and Reay 2007; James and Prout 2015; Lundy and Cook-Sather 2016; Pearce and Wood 2016). In doing so, we considered the conceptualisation and status of students within the various tiers, their positioning and power in the participatory process and the nature of the intergenerational collaboration described. Correspondingly, in line with the scholarship flagged above, the typology is informed by the social construction of childhood as reflected in contemporary Childhood Studies theory (James and Prout 2015) and in recognition theory (Fitzgerald et al. 2010; Thomas 2007, 2012). Grounded in critical theory, the work of recognition scholars is largely interested in self-actualisation, social inequality and social justice. This converging of childhood studies and recognition theory has been found to be fruitful in previous studies by the authors focused on student wellbeing and participation in schools (see, for example, Author et al. 2017) and hence useful in informing the development of the typology. 
With respect to the above, we labelled the uppermost category of our analysis tool 'meaningful', all the while acknowledging that this is a problematic term that gives rise to questions such as, meaningful for whom and under what conditions? Such questions were useful in helping us reach a sense of clarity about our terms for analysis purposes, without being so rigid or aspirational as to be out of alignment with the process of change around student participation. Articulating 'meaningful' in a way that reflected our theoretical foundations and would aid us in analysis, (i.e. making reference to the conceptualisation of students and of participation) we considered a 'meaningful' positioning of student participation to be one in which:

1. Students are presented as actors - full and active members of the school community - who work in partnership with adults and have a stake in the education endeavour, broadly defined;

and / or

2. Participation is framed as having intrinsic value for students (as described in the background section above) - that is in terms of student wellbeing, positive experiences of effecting change or, at least, positive experiences of school and education.

We adopted the term 'tokenistic', popularised in Hart's Ladder of Participation (1992), to refer to those policies that ostensibly promoted the idea of participation (or often 'voice') but were enacted upon students and /or aligned solely to instrumental (or future-orientated) aims. We also created an intermediary category, which we labelled 'partial', for those policies that fell between our 'meaningful' and 'tokenistic' categories (see below). Two additional, non-cumulative categories were added to the typology to record documents that held potential for student participation, but were not sufficiently 
developed to categorise or were intended for other stakeholders. Thus, the final typology used for the analysis comprised the following five categories:

Category 1 - 'Meaningful': Students are presented as actors in the educational process and overall school experience, and / or student participation is framed in terms of student wellbeing and positive experiences of education and school community life

Category 2 - 'Partial': Students are referred to as both actors and as objects to be acted upon and/or student participation is framed in fragmented or contradictory terms

\section{Category 3 - 'Superficial'/tokenistic - students as objects or beneficiaries of} policy: Students are presented as objects to be acted upon and student participation is largely instrumental and/or future-oriented

\section{Category 4 - Articulated but not developed}

Category 5 - Students are not the focus of the policy: Policies intended for stakeholders other than students but may hold potential for addressing student participation

Each of the documents progressed to Stage 2 were allocated to one of the above five categories. In categorising the documents, we were quite liberal in our application of 'meaningful', so as to progress to Stage 3 those policies that might be relevant for this category upon further probing (only those policies allocated to Category 1 were progressed for deeper discursive analysis).

\section{Stage 3: Discursive analysis}

The purpose of Stage 3 was to undertake a thorough discursive analysis of those policies categorised as 'meaningful'. At this stage, we sought to interrogate documentation to investigate whether there had been any engagement with the complex reality of shifting mindsets and mechanisms such that a rights-based, democratic approach might gain traction. While it has been questioned whether it is ever possible to 
truly determine if student participation is 'meaningful' (Barber, 2009), we sought to examine the extent to which a policy might help facilitate the sort of on-going, dialogic intergenerational collaboration described earlier.

Each document was subject to the following series of questions: how is participation framed in the policy; how are students framed (or constructed) in/by the policy; is any relationship articulated between participation and wellbeing and/or implied between participation and children's rights in the policy; what are the types of strategies/mechanisms advocated in the policy for promoting participation. Emergent themes and framings regarding 'students' and 'participation' were then approached and revisited inductively.

\section{Qualitative Interviews with Policy Personnel}

Policy stakeholders from the NSW Government and Catholic school sectors, and covering a range of relevant portfolios (including student wellbeing, Indigenous, disability and leadership), were invited for interview. Potential policy personnel were identified through the research partners and nine agreed to be interviewed (five from the Government and four from the Catholic sector). The interviews took a semi-structured approach, with the aim being to ascertain how these personnel view student participation within current policy priorities, what they consider to be the implicit participation interests in current policy, and whether and how future educational policy might progress these interests. Each interview lasted approximately 40 minutes and was digitally recorded with the participant's permission. The recordings from the interviews were transcribed, coded and analysed for recurring themes and patterns using the NVivo software program. 


\section{Findings}

\section{Analysis of Policy Documents}

The overarching finding from the policy analysis was that there is currently no specific educational policy mandating or supporting student participation in NSW, nor at the federal level in Australia. However, notions of student participation are referred to in a wide range of documents, with 142 identified in Stage 1 of the analysis. These were mapped to different areas/themes, as shown in Table 1. It should be noted that the themes were not a specific point of analysis. However, they do indicate variation in the presence of participation across policy areas.

Table 1: Stage 1 mapping and progress to Stage 2 analysis

\begin{tabular}{lcc}
\hline \multicolumn{1}{c}{ Policy area } & Total & Progressed to Stage 2 \\
\hline Aboriginal education & 8 & 1 \\
$\begin{array}{l}\text { Child protection and out of home } \\
\text { care }\end{array}$ & 11 & 4 \\
Curriculum and school work & 18 & 5 \\
Disability support & 8 & 4 \\
Discrimination & 8 & 6 \\
Education and school planning & 21 & 17 \\
Student welfare and discipline & 39 & 2 \\
Teachers and staff & 8 & 1 \\
Technology and social media & 7 & 3 \\
Values and ethics & 6 & 5 \\
\hline Other & 8 & 50 \\
\hline TOTAL & 142 & 2 \\
\hline
\end{tabular}


Table 1 also highlights the number of policies within each area progressed to Stage 2. In some of the policies discarded at this stage, 'participation' referred to adult-centred engagement between school staff and parents. Alternatively, it was talked about in a broader sense, such as 'community participation', which was generally framed as meaning the relationship and interaction of schools, as institutions, with businesses or civil society organisations. The ways in which students, as individuals or collectively, act within their communities was not the focus of such policies. This reflects the positioning of young people as passive students within the institution of school, rather than as citizens who engage across the social institutions of school, community, family and (for older students) paid work. In total 92 documents were discarded, and 50 were progressed to Stage 2.

As signalled in the Method section above, in the Stage 2 analysis each of the 50 documents was allocated to one of the five categories: meaningful; partial; superficial; articulated but not developed; students are not the focus (see Table 2 for the number allocated to each category, for a full list of these documents see the project report, Authors 2017).

Table 2: Categorisation of documents during Stage 2

Category Number of Policies

\begin{tabular}{ll}
\hline 1. Meaningful & 21
\end{tabular}

2. Partial

6

3. Superficial 12

4. Articulated but not developed 7

5. Students are not the focus 4

Total 50 
Following Stage 2, 21 of the 50 documents were considered to be meaningful (in of terms our definition described earlier) and progressed to Stage 3. Some of these documents were connected (e.g. guidelines accompanying a policy) and these connected documents were grouped such that 15 documents / document sets were progressed to Stage 3 for deeper discursive analysis. These 15 documents are listed in Table 3, below.

Table 3: Documents included in the Stage 3 analysis (categorised as 'meaningful')

\begin{tabular}{|c|c|c|}
\hline NAME (YEAR) & RESPONSIBLE DEPARTMENT & $\begin{array}{l}\text { POLICY AREA } \\
\text { (PHASE 1) }\end{array}$ \\
\hline $\begin{array}{l}\text { National Safe Schools Framework (Revised } \\
\text { 2011) }\end{array}$ & $\begin{array}{l}\text { Ministerial Council on } \\
\text { Education, Early Childhood } \\
\text { Development and Youth } \\
\text { Affairs (Commonwealth) }\end{array}$ & $\begin{array}{l}\text { Education and } \\
\text { school planning }\end{array}$ \\
\hline $\begin{array}{l}\text { AITSL Professional Standards for } \\
\text { Teachers (2011) }\end{array}$ & AITSL (Commonwealth) & Teaching and staff \\
\hline $\begin{array}{l}\text { Australian Curriculum Consultation } \\
\text { Strategy (2013) }\end{array}$ & ACARA (Commonwealth) & $\begin{array}{l}\text { Curriculum and } \\
\text { school work }\end{array}$ \\
\hline Student Welfare Policy (1996) & $\begin{array}{l}\text { NSW Department of } \\
\text { Education and Training }\end{array}$ & $\begin{array}{l}\text { Student welfare and } \\
\text { discipline }\end{array}$ \\
\hline $\begin{array}{l}\text { Environmental Education Policy for } \\
\text { Schools - Implementation Guidelines } \\
\text { (2001) }\end{array}$ & $\begin{array}{l}\text { NSW Department of } \\
\text { Education and Training }\end{array}$ & $\begin{array}{l}\text { Other - } \\
\text { Environment }\end{array}$ \\
\hline Just Like Us (2001) & $\begin{array}{l}\text { NSW Department of } \\
\text { Education and Training }\end{array}$ & Disability support \\
\hline $\begin{array}{l}\text { Healthy School Canteen Strategy (Canteen } \\
\text { Menu Planning Guide) (2004) } \\
\text { Fresh Tastes Tool Kit: Developing a health } \\
\text { school canteen } \\
\text { Healthy Kids [website] }\end{array}$ & $\begin{array}{l}\text { NSW Department of } \\
\text { Education and Training }\end{array}$ & $\begin{array}{l}\text { Student welfare and } \\
\text { discipline }\end{array}$ \\
\hline $\begin{array}{l}\text { School Uniforms in New South Wales } \\
\text { Government Schools (2004) }\end{array}$ & $\begin{array}{l}\text { NSW Department of } \\
\text { Education and Training }\end{array}$ & $\begin{array}{l}\text { Student welfare and } \\
\text { discipline }\end{array}$ \\
\hline $\begin{array}{l}\text { Anti-Racism Policy: What schools can do } \\
\text { [Guidelines] (2010) }\end{array}$ & $\begin{array}{l}\text { NSW Department of } \\
\text { Education and Training }\end{array}$ & Discrimination \\
\hline $\begin{array}{l}\text { Young People and Drugs: a guide for } \\
\text { school staff to support students (2010) }\end{array}$ & $\begin{array}{l}\text { NSW Department of } \\
\text { Education and Training }\end{array}$ & $\begin{array}{l}\text { Student welfare and } \\
\text { discipline }\end{array}$ \\
\hline $\begin{array}{l}\text { Bullying: Preventing and Responding to } \\
\text { Student Bullying in Schools [Policy \& } \\
\text { Guidelines] (2011) }\end{array}$ & $\begin{array}{l}\text { NSW Department of } \\
\text { Education and Training }\end{array}$ & $\begin{array}{l}\text { Student welfare and } \\
\text { discipline }\end{array}$ \\
\hline $\begin{array}{l}\text { Memorandum of Understanding between } \\
\text { NSW Department of Education and } \\
\text { Training and Community Services (2011) } \\
\text { (for students in out-of-home care) }\end{array}$ & $\begin{array}{l}\text { NSW Department of } \\
\text { Education and Training; and } \\
\text { Department of Community } \\
\text { Services }\end{array}$ & Child protection \\
\hline
\end{tabular}




\begin{tabular}{lll}
\hline $\begin{array}{l}\text { Creating Futures Together - DEC } \\
\text { Strategic Directions (2015) }\end{array}$ & $\begin{array}{l}\text { NSW Department of } \\
\text { Education and Communities }\end{array}$ & $\begin{array}{l}\text { School planning } \\
\begin{array}{l}\text { The Wellbeing Framework for Schools } \\
\text { (2015) }\end{array}\end{array}$ \\
$\begin{array}{lll}\text { NSW Department of } \\
\text { Education and Communities }\end{array}$ & $\begin{array}{l}\text { Student welfare and } \\
\text { discipline }\end{array}$ \\
$\begin{array}{l}\text { Understanding and Supporting Children } \\
\text { and Young People's Participation (2015) }\end{array}$ & $\begin{array}{l}\text { Office of the NSW Advocate } \\
\text { for Children and Young } \\
\text { People }\end{array}$ & Values and ethics \\
\hline
\end{tabular}

As Table 3 highlights, the documents categorised as 'meaningful' by the terms of this analysis included three Commonwealth (federal) government documents, 11 documents published by the NSW State Department of Education (the department title changed over time) and one document produced by the NSW Office of the Advocate for Children and Young People. No specific documents from the NSW Catholic sector were progressed to this stage (although it should be noted that this sector is also governed by the Commonwealth documents and several key NSW Catholic sector documents were allocated to Category 4 on the basis that they articulated positive framings of student participation but these were not sufficiently developed to analyse at this stage). All documents were current at the time of review, although they had a wide range of publication dates, covering a 19 year time period $(1996-2015)$.

The key findings of the discursive Stage 3 policy analysis were that there is little consensus across the documentation in the ways that students are conceptualised, nor how participation is framed, even amongst documents produced in the same year and by the same department. In terms of the conceptualisation of students, all of the policies retained to this stage were deemed to position students as actors within the school environment, but considerable variation was found across the documentation in terms of:

1) Whether students are referred to individually or as a collective;

2) The extent to which students are framed as partners in learning or in the school community alongside adults;

and thus, 
3) The scope of their participation (limited / transformative, responsibilisation / emancipation).

In relation to the conceptualisation of participation, eight different framings (or understandings) of participation were identified amongst the 15 documents. In determining these framings, a series of categories was inductively generated, and refined in a cyclical manner, so as not to force policies into a typology. The final eight emergent categories are listed in Table 4. Some policy documents frame participation in a number of ways (producing multiple entries in the table below).

Table 4: How participation is framed in NSW educational policy

\begin{tabular}{|c|c|c|}
\hline $\begin{array}{l}\text { Framing of } \\
\text { participation }\end{array}$ & Brief explanation of framing & Documents in which this framing was identified \\
\hline As consultation & $\begin{array}{l}\text { Student perspectives (voice/s) } \\
\text { are sought on an issue, } \\
\text { although the process } \\
\text { commonly remains controlled } \\
\text { and organised by adults. }\end{array}$ & $\begin{array}{l}\text { Creating Futures } \\
\text { ACARA Curriculum } \\
\text { AITSL National Professional Standards } \\
\text { - Student Welfare Policy } \\
\text { Bullying Policy \& Guidelines } \\
\text { School Uniforms Policy }\end{array}$ \\
\hline As engagement & $\begin{array}{l}\text { Participation is framed as } \\
\text { engagement in school (in } \\
\text { learning and / or the school } \\
\text { community more broadly), } \\
\text { although often difficult to } \\
\text { avoid an instrumental focus }\end{array}$ & $\begin{array}{l}\text { Creating Futures } \\
\text { AITSL National Professional Standards } \\
\text { Wellbeing Framework for Schools }\end{array}$ \\
\hline As connectedness & $\begin{array}{l}\text { Participation is situated at the } \\
\text { intersection between } \\
\text { community, belonging, } \\
\text { wellbeing and relationships, } \\
\text { although limited detail on how } \\
\text { connectedness might be } \\
\text { fostered }\end{array}$ & $\begin{array}{l}\text { National Safe Schools Framework* } \\
\text { Ytudent Welfare Policy } \\
\text { Young People and Drugs } \\
\text { Wellbeing Framework for Schools }\end{array}$ \\
\hline $\begin{array}{l}\text { As positive and } \\
\text { respectful relationships }\end{array}$ & $\begin{array}{l}\text { Participation is equated to } \\
\text { positive and respectful } \\
\text { relations, although again } \\
\text { limited detail on how such } \\
\text { relationships might be } \\
\text { fostered }\end{array}$ & $\begin{array}{l}\text { National Safe Schools Framework* } \\
\text { Young People and Drugs } \\
\text { Wellbeing Framework for Schools }\end{array}$ \\
\hline As equality/inclusion & $\begin{array}{l}\text { Participation is framed in } \\
\text { terms of opportunities for } \\
\text { students from marginalized }\end{array}$ & $\begin{array}{l}\text { Just Like Us* } \\
\text { Memorandum of Understanding (DEC \& } \\
\text { Community Services) }\end{array}$ \\
\hline
\end{tabular}




\begin{tabular}{|c|c|c|c|}
\hline & $\begin{array}{l}\text { groups to feel a sense of } \\
\text { belonging and be fully } \\
\text { included in school life }\end{array}$ & $\%$ & $\begin{array}{l}\text { AITSL National Professional Standards } \\
\text { Anti-Racism Policy Guidelines* } \\
\text { Student Welfare Policy }\end{array}$ \\
\hline As student leadership & $\begin{array}{l}\text { Student representatives are } \\
\text { given 'leadership roles' to } \\
\text { progress a specific aspect of } \\
\text { school life amongst their } \\
\text { peers, although these students } \\
\text { were often given } \\
\text { 'responsibility' rather than } \\
\text { scope to exert agentic } \\
\text { leadership }\end{array}$ & 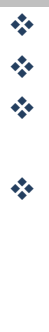 & $\begin{array}{l}\text { Anti-Racism Policy Guidelines } \\
\text { Healthy School Canteen Planning Guide } \\
\text { Environmental Education Policy } \\
\text { Implementation Guidelines } \\
\text { Young People and Drugs }\end{array}$ \\
\hline As a right* & $\begin{array}{l}\text { Direct reference is made to } \\
\text { children's rights to } \\
\text { participation as articulated in } \\
\text { the UNCRC, or reference is } \\
\text { made to students' } \\
\text { 'entitlement' to participation } \\
\text { even if the UNCRC is not } \\
\text { specifically mentioned }\end{array}$ & $*$ & $\begin{array}{l}\text { Understanding and Supporting Children and } \\
\text { Young People's Participation } \\
\text { Memorandum of Understanding (DEC \& } \\
\text { Community Services) } \\
\text { Student Welfare Policy }\end{array}$ \\
\hline $\begin{array}{l}\text { As collective decision } \\
\text { making }\end{array}$ & $\begin{array}{l}\text { Participation is understood as } \\
\text { encompassing opportunities } \\
\text { for influence beyond the } \\
\text { individual level, and } \\
\text { consideration is given to doing } \\
\text { so in manner that moves } \\
\text { beyond participation as } \\
\text { 'representation' }\end{array}$ & $\star$ & $\begin{array}{l}\text { Understanding and Supporting Children and } \\
\text { Young People's Participation }\end{array}$ \\
\hline
\end{tabular}

*Documents marked with an asterisk also use the language of students' 'rights', but the rights mentioned are not participatory rights. For instance, the National Safe Schools Framework refers to students' 'rights...to feel safe and be safe' (p.3). Thus, it is concerned with children's rights to protection rather than participation. In addition, these are not connected to children's protection rights under UNCRC (such as Articles 19, 36 or 37). Just Like Us and the Anti-Racism Policy Guidelines do refer to students' right to participate in activities, but this is in a way that is more aligned with inclusion, rather than notions of voice or dialogue, and again no reference is made to relevant UNCRC articles.

The identification of eight ways of framing student participation across the documentation perhaps reflects, in part, the broad, multi-faceted nature of school life. However, while each framing is arguably legitimate, considerable inconsistencies and tensions were identified between them (as illustrated below). Further, when the eight framings were overlaid upon the range of ways in which students are conceptualised, it signalled that there is very little coherence in the current NSW policy landscape with 
regards to articulations of student participation, even amongst documentation that might be considered 'meaningful' (as per the terms of this analysis). In an effort to elucidate some sense from the existing landscape and identify the areas in which progress is being made, the key findings from this stage are explored below under the headings: student participation in learning and student participation in school community life.

\section{Student participation in learning}

All of the policies retained to Stage 3 presented students as actors in relation to their own learning, challenging the idea of students as passive learners. For instance, in the National Safe Schools Framework (2011) student wellbeing and ownership (Element 7) is described as being characterised by the 'adoption of strength-based approaches to student learning and participation' (p. 8). This implies respect for student agency and their existing experience, and the role students play in their learning. However, not all policies articulated this so explicitly and, as here, these ideas were often not developed such that students might be elevated to partners with teachers in their learning journey.

This is particularly apparent in the AITSL Professional Standards for Teachers (also published in 2011 and at a Commonwealth level). In this document, while students are broadly articulated as actors, they are positioned as being engaged in learning by teachers, with emphasis placed upon teachers' abilities to use a range of verbal and non-verbal communication strategies to support 'student understanding, participation, engagement and achievement' (p.13, Standard 3.5 (with Standard 1.6 articulating a similar notion in relation to students with disability)). There is no clear recognition in the Standards for the agency and self-knowledge that students bring to the learning encounter and concurrently no attention to the development of teachers' skills to facilitate collaborative learning relationships with students. In the absence of this, there is considerable risk that reference 
to participation could be interpreted as 'participating' in lessons, or as a means to support classroom engagement and achievement. This framing is particularly concerning given the centrality of this document to the professional development and employment of teachers nationally.

One of the most egalitarian positionings of students in learning is articulated in the Student Welfare Policy (1996), the longest standing document in this analysis. This document differs from those above in that it not only acknowledges students as 'active participants in the learning process' (p.5), it then also explicitly positions them as 'partners with parents and teachers in the teaching and learning processes at the school' (p. 9 -emphasis added). In doing so, it concomitantly addresses student participation at an individual level (in their own learning journey) and at a collective level (as stakeholders in the teaching as well as learning process). This duality is important. Creating a space for individual students to work in partnership with teachers to develop their own learning plans is an important form of participation and perhaps a viable starting point, especially given its absence from key teaching documents such as the AITSL Standards. However, alone, it offers a narrow understanding of 'matters affecting the child' (Article 12 of the UNCRC). Positioning students as partners in the educational process at school, helps to raise the status of students as a social group and potentially afford opportunities for the sorts of collective, intergenerational collaboration that might challenge existing norms.

In the current policy landscape, there is some provision for collective student participation at a national level, with students invited to share their 'thoughts, feelings, suggestions, questions and recommendations' (web-based) on Australian Curriculum reforms (Australian Curriculum Consultation Strategy 2013). This is a consultative process and students' participatory scope is limited, largely confined to responding to 
proposed content changes, with no opportunity for wider influence nor any indication of how student contributions will be responded to. Nevertheless, this implies a level of recognition of students as an important stakeholder group and represents a clear step towards student 'voice' (and eventually perhaps, dialogue) at a policy level.

\section{Student participation in school community life}

In documents focused upon school life more broadly, students are generally referred to in a collective sense from the outset. Thus, they ostensibly frame students as 'beings' alongside adults and, as a policy suite, afford the student body a say in a wide range of matters at school. However, there is a heavy reliance upon SRCs or the formation of special committees upon which student representatives are positioned as members alongside adult stakeholders, with little attendance to the hegemonic power issues and complexities in translating student perspectives. In fact, in the Wellbeing in Schools Framework (2015) such structures are described as a key mechanism by which to foster relational connections at school. While committees offer one means by which to endeavour to partner with the student body as a collective, the reliance upon such structures across the documentation highlights a concerning conflation between representation and participation.

The Environmental Education Guidelines (2001) might appear to seek to address some of the adult-child power issues inherent to committee-type structures, by referring to student representatives as 'leaders'. However, perhaps in an effort to facilitate student autonomy, these documents are very prescriptive, with targets and outcomes predetermined. This limits student 'leaders' to information gathering and monitoring - to responsibilisation rather than having a participatory role in actively shaping the direction of environmental activities at their school. 
By way of contrast, the tool kit accompanying the Healthy School Canteen Strategy (2004) acts as a resource pack for student leaders, providing templates for designing student surveys, and resources for organising special canteen activities and healthy food themed days. Therefore, it supports student representatives without directing them in their leadership role.

Somewhat similarly, in the action teams advocated by the Anti-Racism Guidelines (2010), students can draw upon their own peer-group insights, being afforded open-ended scope to develop and coordinate anti-racism initiatives that will 'engage the interests of other students' (p.4). Unfortunately, the peer-led approach advocated intimates that leadership should fall to older students, which neglects the capability of younger children both to participate and to take on leadership roles in meaningful ways in schools. The idea that participation might be dependent on the seniority of students, also sits uneasily with some of the other framings of participation found in the analysis, such as positive and respectful relationships or as a right.

Just like Us (2001) (a policy targeting the inclusion of students with disability) was particularly illuminating in terms of conceptualisations of students and participation when considered in comparison to the other documents in the analysis. First, it defines participation as 'more than just being there' (p.4), making explicit the important conceptual and political distinction between presence and participation. This distinction was rarely identified or acknowledged in any of the other documents in the analysis. Second, similarly to the Anti-Racism Guidelines, it places the onus upon students to actively include fellow students with disability, underscoring the importance of peers to the participation and school experience of those living with a disability. However, the level of obligation placed on students for facilitating participation in this document is firmer than the obligation placed on principals and teachers in other documents analysed. 
This suggests that in the current policy landscape there is recognition that students with disability might be marginalised within the student body and school community, but little recognition for the inherent inequality between students and adults more broadly.

Overall, something of a continuum emerged from the Stage 3 analysis in terms of the conceptualisation of student participation. This ranged from students being recognised as actors, but afforded little or no participatory scope (such as in the AITSL Teacher Standards (2011) and the Environmental Education Policy (2001)), through to students being afforded partnership roles both at an individual and collective level across school life (in Student Welfare Policy (1996); Just Like Us (2001); Healthy School Canteen Strategy (2004); The Wellbeing Framework for Schools (2015)). Between these two ends of the continuum were documents in which students are positioned as stakeholders to be consulted with (such as in the Australian Curriculum Consultation Strategy (2013)) or partners at an individual level only (either in learning or wellbeing matters) (this occurs in the Memorandum of Understanding (2011) and Young People and Drugs (2010) documents).

Encompassing the earlier categories from the Stage 2 typology into this continuum, it was found that students are conceptualised within current Australian (NSW) educational policy in the following ways:

- Students are positioned as objects in the educational process and school experience;

- Students are positioned in contradictory ways (as both objects and actors) in the educational process and school experience;

- Students are recognised as actors in the educational process and school experience; 
- Students are positioned as stakeholders to consult with on learning and school community matters;

- Students are positioned as partners with adults at an individual level (in learning or wellbeing matters);

- Students are positioned as partners, at both individual and collective levels, with adults across school life.

Beyond this continuum, the document, Understanding and Supporting Children and Young People's Participation (2015) warrants mention. This document is not specifically an educational policy, being published the by the NSW Advocate for Children and Young People and targeted to any organisation working with children and young people (including schools). Therefore, at present, it fills the gap of an absent overarching educational document on student participation. Given that it is published by the Advocate, it is articulated from a strongly rights-based approach and is explicit in supporting organisations to understand adult-child positionings, the power issues associated with 'listening' and 'hearing' what children have to say, the diversity of children's voices and ethical issues associated with participation. In short, this document offers clearly articulated guidance that challenges mindsets, heralding the potential for an era of change surrounding children's participation in NSW. However, this document has no obligation upon education systems or schools, it exists only to provide guidance and support for those willing to go further to meet Australia's UNCRC obligations.

\section{The Personnel Perspective}

Most policy stakeholders acknowledged that there is little clear guidance on student participation at present in educational policy. Despite this, they were broadly consistent 
in their conceptualisations of student participation, predominantly aligning it with student-centred / individualised learning, almost to the exclusion of discussing participation in other areas of school life. It was acknowledged that certain groups of students are presently offered a more intentional experience of participation in their learning, notably those with additional support needs. Some interviewees envisaged an expansion of this to all students in the near future:

That's going to be a big goal over the next couple of years... giving the ownership to the child...so they can be actively engaged in their learning. (Policymaker 9)

In describing notions of personalised learning, the policymakers largely appeared to position students as partners in the process, albeit solely at an individual level. It was not always easy to disentangle their rationale, but it was largely instrumentally focused - the purpose being to improve students' sense of engagement and to have their needs met more effectively, such that it might enhance achievement potential.

Beyond notions of personalised learning, participation tended to be conceptualised by policy stakeholders in terms of adult-directed consultation. However, most discussed the potential for such consultation in a fairly 'radical' way, both at the school level, to inform school planning, and at a systemic level in relation to the development of educational policy. In both contexts, students were primarily framed as data sources rather than partners, although their lived experiences were recognised as critical to policy and school improvement. Again, it was noted that there is greater imperative to hear from particular groups of students (such as those with disabilities, gifted and talented students, or underachievers) because addressing the needs of these students is more strongly mandated or linked to current policy and/or performance requirements. For the wider school body, it was recognised that the performativity and compliance pressures on schools might be taking priority over meaningful student participation: 
Unfortunately, I think there's a disconnect. The compliance imperatives, the capital A Accountability, driven from MySchool - I don't think lends itself to spending a lot of time thinking about what Year 9 want, to be frank. (Policymakerr 7)

In addition to challenging the impetus for student participation, it was recognised that the compliance agenda can overshadow the influence of students' perspectives:

The other complexity around that is...[if] students would say, "I want a teacher to be fair"... we don’t measure teachers by being fair. (Policymaker 3)

Despite such constraints, several of the policy stakeholders believed that the emphasis on compliance should not limit efforts, and that student participation remains a possibility within the current policy landscape, providing schools are willing to seek out opportunities and adopt more creative thinking. This was evidenced in statements like, 'the mantra of evidence-based decision making is not going to go away' and that the education sector needs to 'see how we can turn it to our own purposes' (Policymaker7). Indeed, some policy stakeholders made quite explicit connections concerning the centrality of student participation to the accountability agenda: 'we're evidence based, we need the evidence, but this is probably the most key thing - that evidence is people's lived experiences...'. (Policymaker 3).

In most interviews, there was broad acknowledgement then of the tensions between performance accountabilities, compliance imperatives and the creativity required to include and respond to students in more participatory ways. A number of the policy personnel pointed to the importance of enabling and supporting grassroots innovation to build momentum, cautioning against policy directives that may lead student participation to become yet another 'tick-box' exercise in schools.

In any change process... you get the early adopters...And then you need to be able to not constrict the evolution of these things by regulation or by bureaucracy. People 
have got to be free to innovate and adapt what is going to work for them. (Policymaker 5)

Both the previous Labor government and the current Federal government have been on the cusp a couple of times in the last six years of making [satisfaction surveys for parents and students] compulsory...We've actually resisted that because our view is...the best way to kill something off is make it compulsory. Everyone just goes through the motions. So we've said, don't make it compulsory but we understand what you're talking about and we encourage it. (Policymaker 7)

Overall, most policy stakeholders perceived that incorporating meaningful student participation into a core evidence-based agenda within education would take time, but was achievable. These was a sense that the education sector is embarking on a process of change towards more inclusive and meaningful participation opportunities for students but that this was taking place at a time when accountability is paramount in policy and there are considerable demands on schools in terms of compliance.

\section{Discussion}

The policy analysis highlighted that while there is no specific educational policy advocating or supporting student participation in the state of NSW nor federally, the term is widely used. However, there is very little definitional clarity, with different conceptualisations of students and participation identified across the broad range of policies included in the document analysis. Such a lack of coordination between policy documents is an issue that has been recognised more broadly in children's rights discourses. In 2003, the UN Committee on the Rights of the Child called for greater coordination between government departments to ensure full compliance with the UNCRC. Over a decade later, Lundy et al. (2012), in their analysis of policy compliance, reiterated that on-going lack of coordination between departments was a primary barrier to effective government delivery for children and young people. Our analysis shows that 
in Australia the need for better coordination remains unresolved and, crucially, that this issue even occurs within Departments/Offices of Education.

While acknowledging the lack of conceptual clarity, educational policy in NSW collectively affords students opportunities to share their views on many facets of school life, and students are positioned as stakeholders of equity in several key national documents. The insights from the policy personnel suggest that this generally promising trend will continue, identifying student partnership in learning and student consultation at a policy and planning level to be key areas of focus in coming years, areas that were noticeably lacking in the existing policy landscape. Assuming that tensions between accountability and compliance pressures and student participation can be navigated, the perspectives of the policy stakeholders interviewed would seem to suggest that policy emphases like personalised learning, might simultaneously open up opportunities for more transformative forms of participation.

However, such developments are arguably dependent upon clearer understandings of student participation amongst all stakeholders. The current lack of conceptual clarity, particularly the frequent use of limiting or instrumental proxy terms - such as consultation and engagement - creates ambiguity regarding the nature and place of student participation. In particular, with very little connection in the existing NSW policy landscape between student participation and its legal imperative as afforded under the UNCRC, there is a risk that it remains an 'added extra' rather than part of the core business of schools (Lundy 2007). That said, the current 'messiness' is perhaps inevitable, given the socioculturally, structurally and politically challenging nature of the concept of student participation (Arnot and Reay 2007; Mannion 2007; Quennerstedt and Quennerstedt 2014; Quinn and Owen 2016; Rizvi and Lingard 2010). In fact, some ambiguity may even be desirable, offering time for experience to help shift beliefs, and 
for transformative thinking and innovation to emerge at the grassroots level, as some of the policy personnel interviewed for this research highlight. However, while a rigid definition of what student participation is and is not may be counter-productive, at least some degree of clarity at a state and national policy level around what participation means and how it can occur would seem essential to create the foundations upon which to continue to progress student participation in schools.

Moreover, without definitional clarity there is a risk that participatory processes do not move beyond the kinds of contained, structured mechanisms teachers feel most comfortable with (Horgan et al. 2017). Indeed, the current lack of coordination may allow a persistence of the structural and power issues that continue to subordinate students as a social group (Arnot and Reay 2007; Fitzgerald et al. 2010; Mannion 2007; Quennerstedt and Quennerstedt 2014; Robinson and Taylor 2013), which may fuel student disinterest and, in turn, reinforce adult perceptions about young people's capabilities and interests with regards to participation. Whilst relationships emerged as one of the framings of participation in the policy analysis, and student-teacher relationships are implicitly gestured towards within notions of partnership, there is little considered attention to the mechanisms by which participation and cultural change might take place. In addition to greater definitional clarity, then, educational policy in NSW would greatly benefit from more transparent acknowledgement of the importance of collaborative intergenerational relationships (see, for example, Fielding 2015; Horgan et al. 2017; Mannion 2010; Mannion Sowerby and l'Anson 2015; Pearce and Wood 2016) and, especially, from guidance on how such relationships can be fostered in practice. 


\section{Conclusion}

The findings presented in this paper suggest that student participation is conceptualised in an uneven and ambiguous way in the state of New South Wales. While 'participation' or associated terms appeared in 142 documents, only 21 documents (15 document sets) referred to student participation in a way that might be experienced as 'meaningful'. Yet even within these there was complexity around the conceptual framing of students and participation, with only a few likely offering scope for the sorts of dialogic, intergenerational relations that might render participation 'meaningful' in practice. Adding to this, the policy personnel pointed to the complexity of progressing student participation in schools, with compliance and accountability obligations creating both opportunities in some arenas and constraints in others.

Despite these difficulties, the findings offer a basis from which to improve policy surrounding student participation, such that educational sectors might better attend to their obligations under the UNCRC. In particular, the collective findings and analyses point to the critical need for greater clarity and cohesion across educational policy about what participation means and how and where it can occur. It seems unlikely that Australia would be unique in this regard (Lundy et al. 2012). To progress this, some form of explicit conceptual framework for understanding student participation in different contexts and for different purposes may be useful. Our analysis suggests one way to approach this would be to promote an agreed understanding of who 'students' are and how they are viewed, alongside more explicit, shared values around the place and purpose/s of 'participation' at school. In this sense, the typology used in our analysis, while conceptually limited in some respects, presents a possible starting point for policy improvement in that it makes explicit the layered ways in which participation can be framed, is aligned with children's rights (as individuals and as a group) as outlined in the 
UNCRC, and offers considerable scope for developing and promoting respectful adultstudent relationships as the basis for participation both in schools and at a policy level.

\section{References}

ABS. 2016. 4221.0 - Schools, Australia, 2016. Canberra: Australian Bureau of Statistics. http://www.abs.gov.au/AUSSTATS/abs@.nsf/allprimarymainfeatures/9448F2F81 4FA0311CA2579C700118E2D?opendocument.

Arnot, M. and D. Reay. 2007. “A Sociology of Pedagogic Voice: Power, Inequality and Pupil Consultation." Discourse: Studies in the Cultural Politics of Education 28 (3): 311-325.

Barber, T. 2009. "Participation, Citizenship, and Well-being: Engaging with Young People, Making a Difference.” Young: Nordic Journal of Youth Research 17 (1): $25-40$.

Bessell, S., and T. Gal. 2009. "Forming Partnerships: The Human Rights of Children in Need of Care and Protection." International Journal of Children's Rights 17: 283-298.

Fielding, M. 2004. “Transformative Approaches to Student Voice: Theoretical Underpinnings, Recalcitrant Realities.” British Educational Research Journal, 30 (2): 295-311.

Fielding, M. 2015. "Student Voice as Deep Democracy." in The Connected School: A Design for Well-Being - Supporting Children and Young People in Schools to Flourish, Thrive and Achieve, edited by C. McLaughlin, 26-32. London: Pearson.

Fitzgerald, R., A. Graham, A. Smith, and N. Taylor. 2010. “Children's Participation as a Struggle over Recognition: Exploring the Promise of Dialogue." in A Handbook 
of Children and Young People's Participation: Perspectives from Theory and Practice, edited by B. Percy-Smith and N. Thomas. London: Routledge.

Graham, A., M.A. Powell, N. Thomas, and D. Anderson. 2017. "Reframing 'WellBeing' in Schools: The Potential of Recognition." Cambridge Journal of Education 47 (4): 439-455.

Hart, R. 1992. Children's Participation: From Tokenism to Citizenship. Florence: UNICEF International Child Development Centre.

.Holdsworth, R. 2000. "Schools That Create Real Roles of Value for Young People." Prospects 30 (3): 349-362. doi:http://dx.doi.org/10.1007/BF02754058.

Horgan, D., C. Forde, S. Martin, and A. Parkes. 2017. “Children's Participation: Moving from the Performative to the Social.” Children's Geographies 15 (3): 274-288. doi:http://dx.doi.org/10.1080/14733285.2016.1219022.

James, A., and A. Prout. 2015. Constructing and Reconstructing Childhood: Contemporary Issues in the Sociological Study of Childhood. New York: Routledge.

Kilbourne, S. 1998. "The Wayward Americans-Why the USA Has Not Ratified the United Nations Convention on the Rights of the Child." Child and Family Law Quarterly 10: 243-256.

Lundy, L. 2007. ““"Voice” is Not Enough: Conceptualizing Article 12 of the United Nations Convention on the Rights of the Child." British Educational Research Journal 33 (6): 927-942.

Lundy, L. 2012. “Children's Rights and Educational Policy in Europe: The Implementation of the United Nations Convention on the Rights of the Child." Oxford Review of Education 38 (4): 393-411. 
Lundy, L., U. Kilkelly, B, Byrne, and J. Kang. 2012. The UN Convention on the Rights of the Child: A Study of Legal Implementation in 12 Countries. Belfast: UNICEF UK.

https://www.qub.ac.uk/researchcentres/CentreforChildrensRights/filestore/Filetoupload\%2C485596\%2Cen.pdf. Lundy, L. and A. Cooksather. 2016. “Children's Rights and Student Voice: Their Intersections and the Implications for Curriculum and Pedagogy." in The $S A G E$ Handbook of Curriculum, Pedagogy and Assessment, edited by D. Wyse, L. Hayward and J. Pandya. London: Sage.

Mannion, G. 2007. “Going Spatial, Going Relational: Why 'Listening to Children' and Children's Participation Needs Reframing." Discourse: Studies in the Cultural Politics of Education 28 (3): 405-420.

Mannion, G. 2010. “After Participation: The Socio-Spatial Performance of Intergenerational Becoming." in A Handbook of Children and Young People's Participation, edited by B. Percy-Smith and N. Thomas. London: Taylor and Francis.

Mannion, G., M. Sowerby, and J. I'Anson. 2015. How Young People's Participation in School Supports Achievement and Attainment. Scotland: Scotland's Commissioner for Children and Young People.

Mitra, D.L. 2006. "Student Voice from the Inside and Outside: The Positioning of Challengers." International Journal of Leadership in Education: Theory and Practice 9 (4): 315-328.

Pearce, T. and B. Wood. 2016. "Education for Transformation: An Evaluative Framework to Guide Student Voice Work in Schools." Critical Studies in 
Education, Published on-line ahead of print. doi:

$10.1080 / 17508487.2016 .1219959$

Quennerstedt, A. and M. Quennerstedt. 2014. 'Researching Children's Rights in Education: Sociology of Childhood Encountering Educational Theory.” British Journal of Sociology of Education 35 (1): 115-132.

Quinn, S., and S. Owen. 2016. "Digging Deeper: Understanding the Power of 'Student Voice'." Australian Journal of Education 60 (1): 60-72. doi:10.1177/0004944115626402.

Raby, R. 2014. “Children's Participation as Neo-Liberal Governance?” Discourse: Studies in the Cultural Politics of Education 35 (1): 77-89.

Rizvi, F. and B. Lingard. 2009. “Globalising Education Policy.” London: Taylor \& Francis.

Robinson, C. and C. Taylor. 2013. "Student Voice as a Contested Practice. Power and Participation in Two Student Voice Projects.” Improving Schools 16 (1): 32-46.

Rudduck, J., and M. Fielding. 2006. "Student Voice and the Perils of Popularity." Educational Review 58 (2): 219-231.

Sargeant J. and J.K. Gillett-Swan. 2015. "Empowering the Disempowered Through Voice-Inclusive Practice: Children's Views on Adult-Centric Educational Provision.” European Educational Research Journal 14: 177-191. https://doi.org/10.1177/1474904115571800.

Shier, H. 2001. "Pathways to Participation: Openings, Opportunities and Obligation." Children \& Society 15 (2): 107-117.

Sinnema, C. E., and I. Ludlow. 2013. "A Rasch Approach to the Measurement of Responsive Curriculum Practice in the Context of Curricula Reform.” 
International Journal of Educational and Psychological Assessment 12 (3): 3340.

Thomas, N. 2007. "Towards a Theory of Children's Participation.” International Journal of Children's Rights 15 (2): 199-218.

Thomas, N. 2012. “Love, Rights and Solidarity: Studying Children's Participation Using Honneth's Theory of Recognition." Childhood 19 (4): 453-466.

United Nations. 1989. Convention on the Rights of the Child. Geneva: Office of the High Commissioner for Human Rights.

UN Committee on the Rights of the Child. 2003. General Comment No. 5. General Measures of Implementation for the Convention on the Rights of the Child, CRC/GC/2003/5. Geneva: Office of the High Commissioner for Human Rights. Yanow, S. 2007. "Interpretation in Policy Analysis: On Methods and Practice.” Critical Policy Analysis 1: 109-121.

\section{Funding:}

This study was supported by an Australian Research Council Linkage grant [No. LP140100540] and the following 'Linkage' partners: Catholic Schools Office, Lismore; NSW Department of Education; and the NSW Advocate for Children and Young People.

\section{Disclosure Statement:}

No financial interest or benefit has arisen from the direct applications of this research. 